\title{
CrimRxiv
}

\section{The Culture of Capital Punishment in Japan}

\section{David T. Johnson}

Published on: Mar 04, 2022

License: Creative Commons Attribution 4.0 International License (CC-BY 4.0). 
